Article

\title{
The Effect of Destination Social Responsibility on Tourists' Satisfaction: The Mediating Role of Emotions
}

\author{
Huynh Anh Thu Tran ${ }^{1}$, Yun Seop Hwang ${ }^{2}$, Cheon Yu ${ }^{3}$ and Seung Jick Yoo ${ }^{4, *}$ \\ 1 Department of International Business and Trade, Kyung Hee University, Seoul 02447, Korea; \\ anhthutran2112@gmail.com \\ 2 Department of International Business and Trade, College of Politics and Economics Kyung Hee University, \\ Seoul 02447, Korea; rusiahys@khu.ac.kr \\ 3 The International Trade Research Center at Kyung Hee University, Seoul 02447, Korea; cheon.yu@khu.ac.kr \\ 4 Department of Convergence of Climate and Environmental Studies, Sookmyung Women's University, \\ Seoul 04310, Korea \\ * Correspondence: sjyoo@sookmyung.ac.kr
}

Received: 29 July 2018; Accepted: 25 August 2018; Published: 27 August 2018

\begin{abstract}
The purpose of this study is to define destination social responsibility as a multidimensional construct and examine the relationships between destination social responsibility, tourists' emotions and their satisfaction, through the lens of corporate social responsibility. A model is empirically tested with a sample of 359 random foreign tourists visiting Hoi An, Vietnam. The results indicate that all destination social responsibility dimensions, including economic, environmental, legal-ethical, and philanthropic responsibilities significantly enhance tourists' emotions, while only legal-ethical and philanthropic responsibilities directly affect tourists' satisfaction. The findings also confirm the mediating effect of emotions between destination social responsibility and tourists' overall satisfaction.
\end{abstract}

Keywords: destination social responsibility; tourists' emotions; tourist satisfaction; Hoi An; Vietnam

\section{Introduction}

Most countries are making great efforts to allure tourists. However, the over-exploitation of natural resources and the over-development of tourism can have negative impacts on the destination's environment, economy, and society, and as a consequence, can harm its long-term health. Given the need to tackle these challenges, or at least diminish undesirable impacts, and to continue to attract tourists, social responsibility practices are acknowledged as one of the most effective solutions for tourism-based organizations [1]. The concept of social responsibility was first introduced in the field of business by Bowen [2] under the term "Corporate Social Responsibility" (CSR). CSR refers to the idea that a corporation should take responsibility for contributing to the community where it operates, since it exists as a legal entity in society. Most of the extant CSR literature has traditionally concentrated on the responsibility of business firms or organizations as individual entities, but has not paid much attention to the combined effects of socially responsible behaviors conducted by interrelated entities in the context of a tourist destination [3-5].

A destination is a holistic construct, in which tourists often depend on the overall perceptions of the destination image to form their behavioral intentions [6]. The collective behaviors related to the social responsibility of all stakeholders can be perceived by tourists, which in turn, form their attitudes about the destination image, and potentially their behavioral intentions. Therefore, it is necessary to study social responsibility based activities from a total destination perspective. From this 
comprehensive perspective, Su et al. [5] defines the term "Destination Social Responsibility" (DSR) as referring to all stakeholders' activities that protect and enhance the social and environmental aspects of an entire destination, beyond the economic interests of the individual organizations. Since there is still a limited understanding of DSR, scholars have energetically called for more research efforts to study this subject. In responding to this, the current study expands on the previous works by developing the DSR construct as a multidimensional construct based on the multidimensional nature of CSR rather than as a one-dimensional construct and further explores the impact of DSR on tourist satisfaction.

Many extant marketing studies have confirmed that socially responsible initiatives have a positive influence on several customer-related outcomes, for example, satisfaction. According to Smith and Ong [7], customers are not willing to consume the goods or services of companies with no or poor socially responsible practices. In line with this understanding, it can be inferred that tourists do not seem to be pleased with tourist sites or travel destinations, which are not environmentally friendly or have socially irresponsible behaviors with regards to local residents. Thus, it is essential to explore the effects of socially responsible activities in the destination on tourists' satisfaction, since the last one is the main factor directly influencing the success of a destination.

To illuminate this relationship, emotions could be considered as a mediator between DSR and tourists' satisfaction [3]. A mediator accounts for the relation between an independent variable and a dependent variable, while a moderator affects the strength of the relation. Therefore, a mediator has a causal relationship with independent variables, but a moderator does not [8]. Emotion is a critical determinant of satisfaction and is a response to the experience of a tourist at a destination [9-12]. This means that emotions mediate the relationship between DSR and tourists' satisfaction. As a mediator, emotions could present the mechanism for understanding how DSR affects tourists' satisfaction [13]. Human behavior is regulated by emotions created by the environment [14]. Therefore, people's emotions determine what they do and how they do it [15] and may result in specific actions to affirm or cope with the emotions [16]. Prior studies have identified the mechanism of emotions, as a mediator on festivals [17], shopping [18], theme parks [19], and holidays [20], but the role of emotions between DSR and tourists' satisfaction has yet to be examined.

Emotions are confirmed to mediate the relationship between perceived DSR and pro-environmental behavioral intentions of tourists [3]. In addition, as the nature of tourism is hedonic, the quest for determinants of tourists' emotions continues to be a challenge for all researchers and practitioners. For this reason, this study adopts emotions as an examined variable to investigate the effects of DSR on tourists' emotions. Simultaneously examining the influences of DSR on both emotions and overall satisfaction is expected to elucidate the research question and propose more useful theoretical and managerial implications for both scholars and destination managers.

The remainder of this paper is organized as follows. Section 2 presents the theoretical background and previous studies on DSR, tourist emotions, and overall satisfaction. Section 3 describes a research model and hypothesis between DSR, tourist emotions, and overall satisfaction. Section 4 presents the methodology applied in this study. Section 5 shows the results of the analysis on the validation and reliability of the research model and hypothesis testing. Section 6 summarizes the results and discuss its implication.

\section{Theoretical Background}

\subsection{Destination Social Responsibility}

Recently, researchers have extended and adopted the main principles of CSR in other various contexts beyond the scope of corporations, such as museums, and heritage [21] and tourist sites [22]. Similarly, the extant CSR works have also been utilized and modified to examine DSR [4,5].

Since a travel destination is a complicated unit including many tourism-related sectors, the effects of socially responsible initiatives on a destination should be considered as the combined CSR effects of all stakeholders operating there [5]. To illuminate these collective CSR effects, Su et al. [5] first 
introduced the term "destination social responsibility" and conceptualized it as the collective ideology and efforts of destination stakeholders to engage in socially responsible activities. They explain that DSR indicates the obligation of all stakeholders in the destination to diminish negative influences on the economy, environment, and society; enhance prosperity for a community and improve the wellbeing of local people. A travel destination could be recognized as a socially responsible destination if all stakeholders of both public and private segments fully engage in socially responsible activities supporting the tourism industry. In a subsequent study, Su et al. [3] suggested that DSR is about the awareness of responsibilities and obligations of all stakeholders, including the government, tourism corporations, organizations, tourists, and community residents to perform socially oriented practices. Su and Swanson [4] defined DSR as activities of stakeholders that protect and improve the social and environmental interests of an entire destination, besides the economic interests of the individual organizations. Sharing the same concept, Ma et al. [23] described DSR as the status and activities applied to all its stakeholders (including governments, investors, suppliers, competitors, local residents, tourists, and employees) in terms with the perception of its social responsibilities.

As mentioned by Su et al. [5], the subject of responsibility in the concept of CSR is obvious, in that responsibility is taken by the corporation or organization under consideration, while in destination settings the identity of the responsible subject is vague. Nevertheless, the accumulation level and performance of the stakeholders' socially responsible behaviors can be theorized and evaluated by the relevant stakeholders, for example, tourists as main evaluators of the destination. Based on this, this study focuses on tourists' evaluation of the effect that socially responsible behaviors at a destination have on their emotions and overall satisfaction.

Su and Swanson [4] point out that DSR includes environmental, social, economic, stakeholders' ethical, legal responsibilities. Ma et al. [23] and Su et al. [3] state that DSR incorporates stakeholders' environmental, social, economic, and voluntary responsibilities. In another study, Su et al. [5] examined DSR with economic, social, environmental, and stakeholder responsibilities. All of these extant studies defined DSR as a one-dimensional construct. However, prior works in CSR literature have confirmed the multidimensional nature of social responsibility. Therefore, relying on the dimensions of CSR, this study extends DSR as a multidimensional construct to examine the effect levels of each dimension. Economic, philanthropic, environment, legal, and ethical dimensions were selected for examination, because these dimensions are frequently adopted in studies related to social responsibility.

\subsection{Tourist Emotions}

Bagozzi et al. [16] conceptualized emotions as "a mental state of readiness that arises from cognitive appraisals of events or thought ... and may result in specific action to affirm or cope with the emotion, depending on its nature and meaning for the person having it". As noted by Westbrook and Oliver [24], customers' emotional responses that are associated with their consumption experiences can be called consumption emotions. In this current study, the perceived responsible activities in a destination evoke tourists' emotions related to consumption experience and form their behavioral intentions. According to Hosany and Prayag [25], prior literature proposed two main theoretical approaches for examining emotions: dimensional (valence based) and categorical (emotion specificity). Dimensional approaches theorize emotions as a limited number of fundamental dimensions, for instance, the Pleasure, Arousal, and Dominance scale [14], or the Positive Affect and Negative Affect Schedule [26]. Categorical approaches conceptualize emotions using a group of discrete emotions, for example, Izard's Differential Emotion Scale [27], Richins' Consumption Emotion Set [28], and Hosany and Gilbert's Destination Emotion Scale [29]. A coherent body of prior research determines the influence of emotional responses to the tourism experience on post-consumption behaviors. Lee et al. [30] demonstrated that the environmental factors of festivals, such as the information, program contents, facilities, and food, have positive influences on the emotions of visitors, which then enhance the tourists' overall satisfaction about the festival. Hosany et al. [31] examined three patterns of emotion-joy, love, and positive surprise-in the relationship with behavioral 
intentions. Their findings confirm that all investigated types of emotions are important antecedents of tourists' favorable behavioral intentions.

\subsection{Overall Satisfaction}

Tourists' overall satisfaction is conceptualized as "the extent of overall pleasure or contentment felt by the visitor, resulting from the ability of the trip experience to realize their desires, expectations, and needs in relation to the trip" [32]. Chon [33] determined that tourist satisfaction is formed on the connection between his/her early expectations about the destination before traveling and the perceived value of the experience at the destination. Hosany and Prayag [25] defined tourist satisfaction as a summative overall construct related to tourists' overall evaluation of a destination and their experience in the destination. The main focus of prior works on tourists' satisfaction relates to its antecedents and later behavioral intentions. Um et al. [34] found that perceived attractiveness, perceived quality of service, and perceived value for money are powerful predictors of tourists' overall satisfaction. Kozak and Rimmington [35] determined that tourists, who are satisfied with their travel experiences in Mallorca, Spain, will tend to come back and recommend the destination to others. Besides, satisfied visitors are more willing to recommend their holidays than to revisit the destination.

\section{Research Model and Hypothesis Development}

\subsection{Research Model}

The research model is depicted in Figure 1. DSR is conceptually categorized into five dimensions and each has a direct and an indirect relationships with emotions and overall satisfaction. Emotions are introduced as the mediating variable and designed to show the indirect effect of DSR on overall satisfaction.

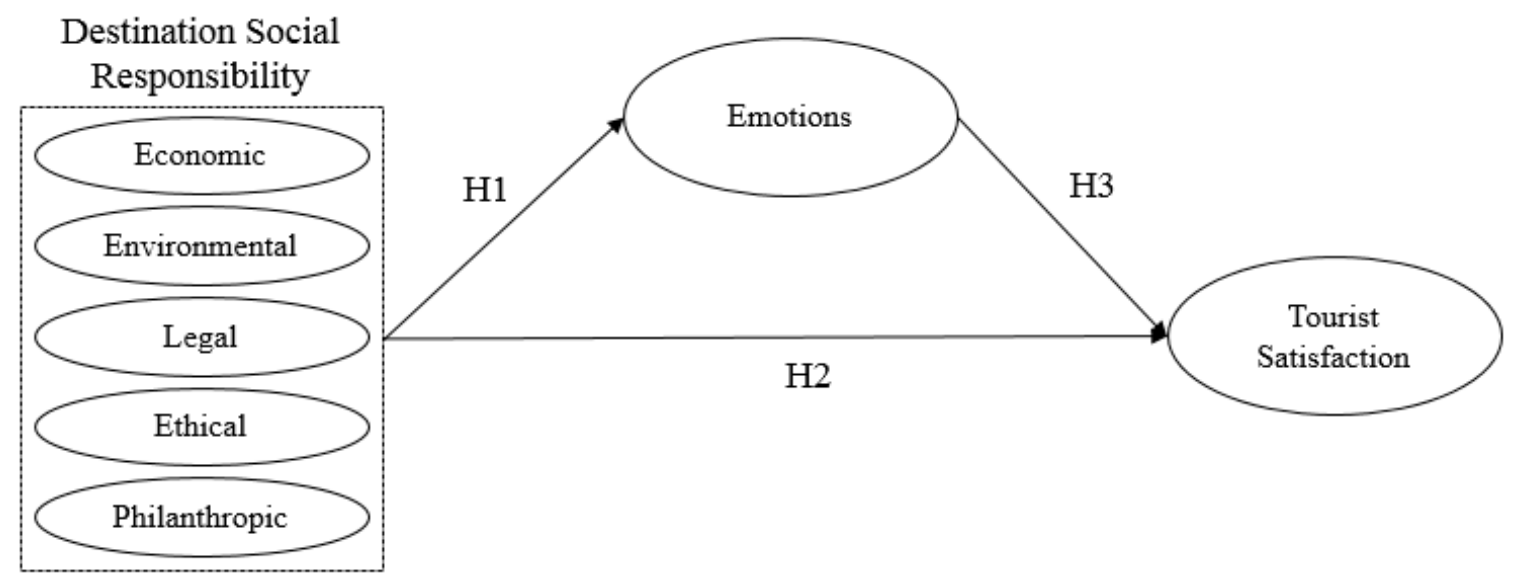

Figure 1. Research model.

\subsection{Hypothesis Development}

\subsubsection{Destination Social Responsibility and Tourists' Emotions}

According to the Hierarchy of Effects Model, under the effects of advertising, customer behavior undergoes 3 stages: (1) the cognitive stage, which indicates customers' perceptions and thoughts; (2) the affective stage, denoting the changes of emotions; and (3) the cognitive stage, which refers to intentions and behaviors. From the viewpoint of marketing, the social responsible activities of a company can be regarded as "image advertisement," which concentrates on originating attitudes and feelings for customers [36]. A good corporate image from social responsibility can help consumers have a good impression and good feelings towards the enterprise. The same principle could be applied in the destination settings. Socially responsible activities perceived at the destination could enhance a 
tourist's image of the destination. Tourists who have a favorable image of a location would perceive their onsite experiences positively, including both cognitive and affective experiences (happy, good, pleased, etc.) [37].

Su et al. [38] noted that customers could receive benefits when they see a company's responsible activities supporting their ethical views and goals. Here, the benefits can be understood as symbolic benefits that help customers satisfy their self-improvement and personal uniqueness needs [39]. By receiving symbolic benefits, they expect positive emotions to be evoked as a consequence. Su and Swanson [4] considered that "tourists might construe an overall destination's attention to socially responsible issues as facilitating their own moral interests". Similarly, tourists can receive the symbolic benefits by regarding DSR practices as supporting their society's goals [4]. As a result, positive emotions can be elicited.

Relying on the Stimulus-Organism-Response (S-O-R) framework [14], Su and Swanson [4] consider perceived socially responsible behaviors in the destination as stimuli (S) and emotional responses associated with consumption experiences as internal states $(\mathrm{O})$, which then lead to behavioral intentions of tourists (R). From what have discussed above, it is hypothesized as following:

Hypothesis 1 (H1). Destination social responsibility has a positive effect on tourists' emotions.

\subsubsection{Destination Social Responsibility and Overall Satisfaction}

CSR can significantly promote consumers' evaluations of and attitudes toward an enterprise [40]. Particularly, some recent studies explored that CSR practices stimulate customers to develop a close relationship with the company that can later form customer-company identification [41,42]. Undoubtedly, customers who have a positive attitude towards the company are likely to be satisfied with the firm's offerings [39,43]. In the context of destination, Su and Swanson [4] found that DSR has a positive effect on tourist-destination identification. Thus, it can be inferred that tourists who identify with destination will be more satisfied with the destination.

As mentioned above, socially responsible activities can generate the perceptions of a good destination image. Many prior works have confirmed that destination image can affect tourists' overall satisfaction [44-46]. Therefore, it can be believed that socially responsible activities in the destination can have an influence on tourists' satisfaction. At the destination level, DSR practices can boost the residents' overall satisfaction with the destination [3]. Thus, it is hypothesized as following:

Hypothesis 2 (H2). Destination social responsibility has a positive effect on tourists' overall satisfaction.

\subsubsection{Tourists' Emotions and Overall Satisfaction}

Emotions appearing from consumption experiences may affect "memory traces which consumers process and integrate to form consumption evaluations of satisfaction" [47]. Ladhari [9] confirmed that emotional states have positive impacts on customers' satisfaction in consumption experience, which then leads to positive word-of-mouth intention. Yuksel and Yuksel [10] pointed out that pleasure and arousal experienced while shopping in a destination can positively influence tourists' shopping satisfaction. Jung and Yoon [12] investigated whether positive emotions, such as entertainment, happiness, pleasure, and delight, lead to customer satisfaction in a restaurant. Io [11] stated that emotional experiences in a casino-hotel, such as light pleasure and intensive fun, can enhance visitors' satisfaction. It is shown in the study by Prayag et al. [47] that joy, love, and positive surprise have a significant impact on satisfaction in the context of heritage tourism. Positive emotions are associated with the generation of satisfaction with tourist services, for example, theme parks [48]. In the study by Hosany et al. [31], tourists' emotional experiences are acknowledged as significant determinants of satisfaction. Accordingly, the following hypothesis is formulated below: 
Hypothesis 3 (H3). Tourists' emotions have a positive effect on tourists' overall satisfaction.

\section{Methodology}

\subsection{Operational Definitions}

The definition of DSR used in this study follows that of Su et al. [5]. Dimensions of DSR are defined based on the prior works of Carroll [49,50], Dahlsrud [51], Jang [52], and Su et al. [5]. Economic responsibility is the effort made by destination stakeholders to be profitable and share the economic benefits with society $[5,49,50]$. Environmental responsibility is the effort made by destination stakeholders to perform environmentally friendly practices and protect the environment along with operating their businesses $[5,51,52]$. Philanthropic responsibility is the effort made by destination stakeholders to use the revenue generated through business for social activities or donations $[5,49]$. Legal responsibility is the effort made by destination stakeholders to observe customer-related regulations, law, and government regulations [5,49,52]. Ethical responsibility is the effort made by destination stakeholders to prevent ethical norms from being compromised to achieve a company's goals and circumventing social harm, as well as acting ethically towards stakeholders $[5,49,52]$. Emotions are defined based on the study of Bagozzi et al. [16]. The definition of satisfaction is also grounded in the study of Chen and Tsai [32].

\subsection{Measurement Items}

The questionnaire was originally developed in English (Table 1). Then, it was translated into Korean and Chinese by bilingual speakers, due to the increasing number of Korean and Chinese tourists travelling to Vietnam in recent years. The questionnaires were also carefully checked by different native speakers of Korean and Chinese to eliminate errors and ensure that no meaning was lost when compared to the original questionnaire. Finally, all three of versions (English, Korean, and Chinese) were used for this study. All the measurement items were adopted from prior works and modified to match the research model and context of the present study. All the constructs employed in the present study were assessed with 5-point Likert-type scales, anchored by strongly disagree (1) and strongly agree (5).

Table 1. Measurement items.

\begin{tabular}{lll}
\hline Constructs & \multicolumn{1}{c}{ Measurement Items } & References \\
\hline & "I thought that local authority, service providers, \\
and companies in Hoi An ..." & 1. tried to generate tourism profits. \\
2. improved the quality of their services and products. & 3. $\quad$ made contributions to the national and local economy \\
Economic Responsibility & through their businesses. \\
& 4. $\quad$ tried to generate employment through their operations. \\
& 6. $\quad$ established long-term plans for their businesses. \\
7. & encouraged tourists to consume/use local products.
\end{tabular}


Table 1. Cont.

\begin{tabular}{|c|c|c|c|}
\hline Environmental Responsibility & $\begin{array}{l}1 . \\
2 . \\
3 . \\
4 . \\
5 . \\
6 . \\
6 .\end{array}$ & $\begin{array}{l}\text { were concerned with protecting the environment. } \\
\text { used energy efficiently to protect the environment. } \\
\text { recycled waste. } \\
\text { used environmentally friendly products. } \\
\text { offered environment-friendly products and } \\
\text { travel programs. } \\
\text { encouraged tourists to be environmentally friendly } \\
\text { when in nature. } \\
\text { communicated with tourists about their } \\
\text { environmental practices. }\end{array}$ & [52-54] \\
\hline Legal Responsibility & $\begin{array}{l}1 . \\
2 . \\
3 . \\
4 .\end{array}$ & $\begin{array}{l}\text { protected consumers and took responsibility for their } \\
\text { products/services. } \\
\text { resolved service problems promptly. } \\
\text { observed legal responsibilities and standards. } \\
\text { treated customers honestly and ethically. }\end{array}$ & {$[52]$} \\
\hline Ethical Responsibility & $\begin{array}{l}1 . \\
2 . \\
3 . \\
4 . \\
5 . \\
6 .\end{array}$ & $\begin{array}{l}\text { did not practice exaggerated and false advertisements. } \\
\text { provided customers with full and accurate information } \\
\text { about products/services. } \\
\text { considered tourists' satisfaction as highly important. } \\
\text { established ethical guidelines for business activities. } \\
\text { tried to become the ethically trustworthy } \\
\text { service providers. } \\
\text { provided a healthy and safe working environment } \\
\text { for employees. }\end{array}$ & {$[36,52]$} \\
\hline Philanthropic Responsibility & $\begin{array}{l}1 . \\
2 . \\
3 . \\
4 .\end{array}$ & $\begin{array}{l}\text { did charitable activities. } \\
\text { played a role in society that went beyond mere } \\
\text { profit generation. } \\
\text { tried to fulfill its social responsibility. } \\
\text { actively participated in social and cultural events. }\end{array}$ & {$[52,55-57]$} \\
\hline Emotions & $\begin{array}{l}\text { “T } \\
1 . \\
2 . \\
3 .\end{array}$ & $\begin{array}{l}\text { ough my experience in Hoi An, ..." } \\
\text { I felt happy. } \\
\text { I felt relaxed. } \\
\text { I felt excited. }\end{array}$ & [4] \\
\hline Overall Satisfaction & $\begin{array}{l}1 . \\
2 . \\
3 . \\
4 .\end{array}$ & $\begin{array}{l}\text { Overall, I was satisfied with this destination. } \\
\text { Overall, my experience in Hoi An was much better than } \\
\text { my expectations. } \\
\text { Given all things considered (e.g., time, effort, money), I } \\
\text { was satisfied with my visit to Hoi An. } \\
\text { This was the best destinations I had visited. }\end{array}$ & {$[28,58]$} \\
\hline
\end{tabular}

\subsection{Data Collection and Sampling}

This study carried out in Hoi An, Vietnam. Hoi An has an ancient town, which was recognized as a World Heritage Site in 1999 by UNESCO, and the Cham Islands, a World Biosphere Reserve. Along with the rapid tourism development in Hoi An, the local government has encouraged enterprises to engage 
in socially responsible actions and made heavy investments in protecting the natural environment and heritage areas. Thus, Hoi An, well-known for its traditional assets and natural beauty, brings an appropriate context for our study to examine how DSR can perform to help to preserve the natural environment and heritage sites, and hence continue to draw tourists.

The convenience sampling technique and a self-administered questionnaire method were applied to collect data from 23 August to 8 September 2017. The target subjects for this study were international tourists visiting Hoi An. The respondents were given a small gift after completing the questionnaire. A total of 371 questionnaires were received, and 359 valid ones could be finally used in this study. The sample characteristics of the sample are shown in Table 2.

Table 2. Demographic characteristics of respondents $(\mathrm{N}=359)$.

\begin{tabular}{cccccccc}
\hline Category & Classification & $\mathbf{N}$ & $\mathbf{\%}$ & Category & Classification & $\mathbf{N}$ & $\mathbf{\%}$ \\
\hline \multirow{5}{*}{ Nationality } & Europe & 159 & 44 & & $20-29$ & 154 & 43 \\
& Asia & 124 & 34 & & $30-39$ & 89 & 25 \\
& Australia & 49 & 14 & Age & $40-49$ & 59 & 16 \\
& America & 25 & 7 & & $50-59$ & 47 & 13 \\
& Africa & 2 & 1 & & 60 and older & 10 & 3 \\
\hline \multirow{3}{*}{ Gender } & Male & 181 & 50 & & Less than $\$ 10,000$ & 41 & 11 \\
& Female & 178 & 50 & & $\$ 10,000$ to $\$ 29,999$ & 53 & 15 \\
\cline { 6 - 8 } Education & High school & 52 & 15 & Annual Income & $\$ 30,000$ to $\$ 49,999$ & 50 & 14 \\
& College/University & 235 & 65 & Level (USD) & $\$ 50,000$ to $\$ 69,999$ & 74 & 21 \\
& Graduate school & 72 & 20 & & $\$ 70,000$ to $\$ 99,999$ & 75 & 21 \\
& & & & & More than $\$ 100,000$ & 66 & 18 \\
\hline
\end{tabular}

\section{Empirical Results}

The surveyed data were analyzed through three steps. First, exploratory factor analysis was conducted to assess the validity of measurement scales. Next, confirmatory factor analysis was performed to determine how well the manifest variables expressed the constructs and to identify the goodness of fit of the proposed model. Finally, the hypothesized relationships among DSR, emotional responses, and satisfaction were examined utilizing a structural equation model.

\subsection{Validation and Reliability}

First of all, the Kaiser-Meyer-Olkin measure and Bartlett's test of sphericity were carried out to evaluate whether the data was appropriate for factor analysis. The Kaiser-Meyer-Olkin measure was 0.914 and Bartlett's Test of sphericity was significant $(p<0.001)$, confirming that the surveyed data was highly suitable for using factor analysis.

The results of exploratory factor analysis using the principal component method with VARIMAX rotation are presented in Table 3. The eigenvalues greater than 1 and the proportion of variance criterion indicated that seven factors could be extracted from data that captured $76.14 \%$ of the total variance. As noted by Hair et al. [59], factor loadings should be greater than 0.50 . Among 28 items of DSR, six items were eliminated because of low factors loadings $(<0.50)$. In particular, ethical responsibility and legal responsibility merged into one construct through the factor analysis process. Since tourists maybe consider ethical responsibility and legal responsibility as the same concept, the author decided to rename this dimension "Ethical-legal responsibility" and used this construct for further analysis. In the study of Lee and Son [60], ethical-legal responsibility was examined as one dimension of CSR. They explained that there might have the correlations between dimensions of CSR. Next, the scale reliability of each factor was investigated with the Cronbach's alpha value. All seven factors exceeded the threshold of 0.70 , ranging from 0.838 to 0.952 , indicating the high-reliability coefficients of the factors. 
Table 3. Results of validation and reliability.

\begin{tabular}{|c|c|c|c|c|c|c|}
\hline Constructs & Items & $\begin{array}{l}\text { Factor Loading } \\
\text { (EFA) }\end{array}$ & $\begin{array}{c}\text { Cronbach's } \\
\text { Alpha }\end{array}$ & $\begin{array}{l}\text { Std. Loading } \\
\text { (CFA) }\end{array}$ & CR & AVE \\
\hline \multirow{6}{*}{ Economic } & Economic 1 & 0.805 & \multirow{6}{*}{0.948} & 0.811 & \multirow{6}{*}{0.959} & \multirow{6}{*}{0.799} \\
\hline & Economic 2 & 0.848 & & 0.850 & & \\
\hline & Economic 3 & 0.881 & & 0.890 & & \\
\hline & Economic 4 & 0.875 & & 0.884 & & \\
\hline & Economic 5 & 0.860 & & 0.867 & & \\
\hline & Economic 6 & 0.902 & & 0.906 & & \\
\hline \multirow{6}{*}{ Environmental } & Environment 1 & 0.753 & \multirow{6}{*}{0.888} & 0.728 & \multirow{6}{*}{0.890} & \multirow{6}{*}{0.574} \\
\hline & Environment 3 & 0.749 & & 0.736 & & \\
\hline & Environment 4 & 0.771 & & 0.733 & & \\
\hline & Environment 5 & 0.720 & & 0.726 & & \\
\hline & Environment 6 & 0.824 & & 0.796 & & \\
\hline & Environment 7 & 0.832 & & 0.811 & & \\
\hline \multirow{6}{*}{ Legal-Ethical } & Legal 1 & 0.735 & \multirow{6}{*}{0.922} & 0.751 & \multirow{6}{*}{0.934} & \multirow{6}{*}{0.705} \\
\hline & Legal 2 & 0.867 & & 0.849 & & \\
\hline & Ethical 1 & 0.816 & & 0.825 & & \\
\hline & Ethical 2 & 0.837 & & 0.845 & & \\
\hline & Ethical 3 & 0.768 & & 0.747 & & \\
\hline & Ethical 4 & 0.862 & & 0.880 & & \\
\hline \multirow{4}{*}{ Philanthropic } & Philanthropic 1 & 0.865 & \multirow{4}{*}{0.919} & 0.870 & \multirow{4}{*}{0.944} & \multirow{4}{*}{0.809} \\
\hline & Philanthropic 2 & 0.871 & & 0.881 & & \\
\hline & Philanthropic 3 & 0.813 & & 0.785 & & \\
\hline & Philanthropic 4 & 0.872 & & 0.906 & & \\
\hline \multirow{3}{*}{ Emotions } & Emotion 1 & 0.764 & \multirow{3}{*}{0.838} & 0.714 & \multirow{3}{*}{0.886} & \multirow{3}{*}{0.724} \\
\hline & Emotion 2 & 0.809 & & 0.904 & & \\
\hline & Emotion 3 & 0.788 & & 0.779 & & \\
\hline \multirow{4}{*}{ Overall Satisfaction } & Satisfaction 1 & 0.854 & \multirow{4}{*}{0.952} & 0.874 & \multirow{4}{*}{0.973} & \multirow{4}{*}{0.899} \\
\hline & Satisfaction 2 & 0.847 & & 0.919 & & \\
\hline & Satisfaction 3 & 0.841 & & 0.902 & & \\
\hline & Satisfaction 4 & 0.889 & & 0.958 & & \\
\hline
\end{tabular}

Note. EFA: exploratory factor analysis, CFA: confirmatory factor analysis, CR: composite reliability, AVE: average variance extracted. Economic 7, Environmental 2, Legal 3-4, Ethical 5-6 of the measurement items were removed because of low factor loadings.

Confirmatory factor analysis was then undertaken to confirm the goodness of fit for the measurement model and test discriminant validity and convergent validity of constructs. The analysis results were as follows: $\mathrm{x}^{2}=541.801, \mathrm{CMIN} / \mathrm{df}=1.497, p=0.000$, Goodness of Fit Index $=0.909$, Adjusted GFI $=0.891$, Normed Fit Index $=0.936$, Comparative Fit Index $=0.978$, Root Mean squared Residual $=0.029$, Root Mean Squared Error of Approximation $=0.037$. This indicates that the model has an acceptable fit.

Convergent validity is generally examined by factor loading, average variance extracted (AVE) and composite reliability. All standardized item loadings exceeded this threshold. The AVE scores were above the required value of 0.5 , ranging from 0.575 to 0.899 , showing that the variance generated by the corresponding constructs is greater than the variance due to measurement errors. All values of composite reliability were over the 0.7 thresholds suggested by Hair et al. [59]. Since all the AVE values and the composite reliability indices were satisfactory, the measurement model was confirmed to have good convergent validity.

As can be seen from Table 4, all the squared values of correlations between constructs ranged from 0.04 to 0.236 , which were lower than the smallest AVE value of 0.574 . This means that the discriminant validity of all constructs was satisfactory. 
Table 4. Means, standard deviation, and correlations of all variables.

\begin{tabular}{lcccccccc}
\hline \multicolumn{1}{c}{ Variables } & Mean & SD & $\mathbf{1}$ & $\mathbf{2}$ & $\mathbf{3}$ & $\mathbf{4}$ & $\mathbf{5}$ & $\mathbf{6}$ \\
\hline 1. Economic Res. & 3.28 & 0.78 & 1 & & & & & \\
2. Environment Res. & 2.80 & 0.80 & $0.372^{* *}$ & 1 & & & & \\
3. Legal-Ethical Res. & 3.50 & 0.78 & $0.229^{* *}$ & $0.243^{* *}$ & 1 & & & \\
$\begin{array}{l}\text { 4. Philanthropic Res. } \\
\text { 5. Emotions }\end{array}$ & 3.74 & 0.74 & $0.242^{* *}$ & $0.200^{* *}$ & $0.282^{* *}$ & 1 & & \\
6. Overall & 3.76 & 0.73 & $0.369^{* *}$ & $0.303^{* *}$ & $0.455^{* *}$ & $0.327^{* *}$ & 1 & \\
Satisfaction & 3.96 & 0.70 & $0.261^{* *}$ & $0.273^{* *}$ & $0.445^{* *}$ & $0.486^{* *}$ & $0.402^{* *}$ & 1 \\
\hline
\end{tabular}

Note. ${ }^{* *} p<0.01$.

\subsection{Results of Hypothesis Testing}

To identify the validity of the proposed model and examine the hypothesized relationships among all variables, this study utilized a structural equation model with AMOS 20. Similar to the evaluation process of the measurement model, the fit indices, such as GFI, AGFI, NFI, RMSEA, were adapted to measure the goodness of fit of the research model. The used data showed an acceptable fit of the model as follows: $\mathrm{x}^{2}=541.801, \mathrm{CMIN} / \mathrm{df}=1.497, p=0.000, \mathrm{GFI}=0.909, \mathrm{AGFI}=0.891, \mathrm{NFI}=0.936, \mathrm{CFI}=0.978$, $\mathrm{RMR}=0.029$, RMSEA $=0.037$. Therefore, the proposed model was reliable and appropriate for testing the relationships among the variables. Table 5 illustrates the results for the hypotheses. The first hypothesis proposed that DSR has a positive impact on tourists' emotions. From Table 5, it was revealed that tourists' perceptions of all four dimensions of social responsibility in the destination (economic, environmental, legal-ethical, and philanthropic) had significant effects on emotions. The legal-ethical responsibility had the greatest influence with $\beta=0.364(p<0.01)$, followed by economic responsibility with $\beta=0.206(p<0.01)$. The philanthropic responsibility and environmental responsibility also positively affected emotional responses with $\beta=0.174(p<0.01)$ and $\beta=0.120(p<0.05)$ respectively. Hypothesis 2, that is, DSR has a positive effect on tourists' satisfaction, was partially supported. Only the legal-ethical and philanthropic dimensions significantly influenced satisfaction $(\beta=0.258$ and 0.355 , respectively; $p<0.01$ ) while there was no relationship between economic responsibility, environmental responsibility, and satisfaction. The relationship between emotions and satisfaction was supported with $\beta=0.153(p<0.05)$. Hypothesis 3 was supported.

Table 5. Hypotheses testing results.

\begin{tabular}{|c|c|c|c|c|c|}
\hline & Path & S.P.L ${ }^{a}$ & S.E ${ }^{b}$ & $t$ Value & $p$ Value \\
\hline \multirow{4}{*}{$\mathrm{H} 1$} & Economic Res. $\rightarrow$ Emotions & 0.206 & 0.053 & 3.742 & 0.000 \\
\hline & Environmental Res. $\rightarrow$ Emotions & 0.120 & 0.054 & 2.127 & 0.033 \\
\hline & Legal-Ethical Res. $\rightarrow$ Emotions & 0.364 & 0.052 & 6.663 & 0.000 \\
\hline & Philanthropic Res. $\rightarrow$ Emotions & 0.174 & 0.055 & 3.269 & 0.001 \\
\hline \multirow{4}{*}{$\mathrm{H} 2$} & Economic Res. $\rightarrow$ Overall Satisfaction & 0.023 & 0.044 & 0.444 & 0.657 \\
\hline & Environmental Res. $\rightarrow$ Overall Satisfaction & 0.083 & 0.044 & 1.600 & 0.110 \\
\hline & Legal-Ethical Res. $\rightarrow$ Overall Satisfaction & 0.258 & 0.046 & 4.725 & 0.000 \\
\hline & Philanthropic Res. $\rightarrow$ Overall Satisfaction & 0.355 & 0.046 & 7.008 & 0.000 \\
\hline H3 & Emotions $\rightarrow$ Overall Satisfaction & 0.153 & 0.054 & 2.529 & 0.011 \\
\hline
\end{tabular}

The direct, indirect, and total effects in the structural model are reported in Table 6. Both philanthropic responsibility and legal-ethical responsibility had significant direct influences on satisfaction, whereas economic responsibility and environmental responsibility did not directly affect tourists' overall satisfaction. However, all examined responsibilities were found to have considerable indirect impacts on satisfaction, due to the mediating effect of emotions. To be specific, legal-ethical responsibility had the most influential indirect effect on tourists' overall satisfaction 
via emotions with $\beta=0.056$ ( $p<0.01$ ), subsequently followed by economic responsibility ( $\beta=0.032$, $p<0.01)$, philanthropic responsibility $(\beta=0.027, p<0.01)$ and environmental responsibility $(\beta=0.018$, $p<0.01$ ). Thus, the mediating role of emotions between DSR and satisfaction was verified through empirical results. In other words, the positive link of "DSR $\rightarrow$ tourists' emotions $\rightarrow$ satisfaction" was confirmed. This also means that economic responsibility and environmental responsibility will not influence tourists' satisfaction without the mediation effect of emotions. In terms of total effects, philanthropic responsibility had the greatest effect on satisfaction $(\beta=0.382, p<0.01)$, in comparison with legal-ethical responsibility $(\beta=0.313, p<0.01)$ and environmental responsibility $(\beta=0.102$, $p<0.01)$. Meanwhile, there was no total effect between economic responsibility and satisfaction.

Table 6. Results of total effects, direct effects, and indirect effects.

\begin{tabular}{|c|c|c|c|c|c|}
\hline \multirow{2}{*}{\multicolumn{3}{|c|}{ Path }} & \multicolumn{3}{|c|}{ Standard Path Loadings } \\
\hline & & & Total Effects & Direct Effects & Indirect Effects \\
\hline Economic Res. & $\rightarrow$ & \multirow{4}{*}{ Satisfaction } & 0.054 & 0.023 & 0.032 ** \\
\hline Environmental Res. & $\rightarrow$ & & $0.102^{* *}$ & 0.083 & $0.018^{* *}$ \\
\hline Legal/Ethical Res. & $\rightarrow$ & & $0.313^{* *}$ & $0.258^{* *}$ & $0.056^{* *}$ \\
\hline Philanthropic Res. & $\rightarrow$ & & $0.382 * *$ & $0.355^{* *}$ & $0.027^{* *}$ \\
\hline
\end{tabular}

\section{Discussion and Conclusions}

This study presented a theoretical model that explored whether tourists' perceptions towards socially responsible behaviors in a destination affected their emotional responses, which in turn could influence their satisfaction later on. This study is slightly different from other related studies in terms of conceptualizing DSR as a five-dimensional construct and examining the different influence levels of these dimensions on tourists' emotions and overall satisfaction. The findings revealed that all investigated responsibility dimensions had significant impacts on tourists' emotional experience at the destination. According to Su and Swanson [4], because they are unfamiliar with the destination, the first-time tourists tend to depend more on evaluations of DSR as an important piece of information to develop a sense of having a relationship with the destination. Since $84 \%$ of respondents in this study were first-time tourists to the destination, the survey received active responses to questions about DSR initiatives, helping to elicit the emotions of the respondents. Among four significant DSR dimensions, the legal-ethical dimension was found to be the most important one in influencing tourists' emotions. From the perspective of service consumers, tourists might hope to be treated with respect and equality first and foremost. Interestingly, only legal-ethical responsibility and philanthropic responsibility had a significant influence on overall satisfaction, while economic responsibility and environmental responsibility showed no relationship with satisfaction. The reason may be that tourists can only feel satisfied when their personal interests or expectations are achieved. Economic responsibilities with a guarantee of business viability, and environmental responsibilities with a focus on environmental protection did not seem to directly affect the benefits and expectations of tourists. In contrast, legally-ethically responsible behaviors, such as protecting customer rights or not applying false advertisements, can directly enhance tourists' travel experience, while the philanthropic responsibility of enterprises can help to fulfill tourists' vicarious satisfaction. Additionally, this study contributed to tourism theory by identifying the mediating roles of emotions on the relationship between tourists' perceived DSR and their satisfaction. Although both economic and environmental responsibilities did not pose a direct impact on tourists' satisfaction, these two dimensions elicited tourists' emotional responses, which in turn positively affected their overall satisfaction. To put it differently, the economic and environmental responsibilities had only indirect effects on tourists' satisfaction through the mediating effect of emotions. The findings confirmed the direct positive relationship between emotions and satisfaction that were consistent with previous empirical works e.g., [9-12]. 
Through empirical findings from the present study, several managerial implications could be inferred for those who are responsible for the marketing and management of tourist destinations. First, findings showed that if a destination can create a deep impression of strong social responsibility, it will satisfy tourists who may be repeat customers or recommend the destination to other potential future customers. It can be implied that increasing investments in socially responsible conducts can bring useful economic benefits in the long term. Therefore, destination-marketing managers should consider DSR activities. Second, since emotions are found to play an important role in mediating the influences of socially responsible practices on satisfaction, destination marketers should focus on other marketing activities in a way that evokes visitors' emotions, which ultimately increases the satisfaction level of tourists. For example, Taiwan adopts the slogan "Touch Your Heart" to bring feelings of warm-heartedness to their potential tourists, and the Netherlands stimulates tourists' curiosity with the slogan "Surprising Cities". Third, since the awareness of socially responsible practices in the destination is expected to be relatively low when compared to the CSR of individual corporations, destination planners and marketers should call for synergy between all stakeholders to encourage DSR activities and set it as a long-term strategic planning goal. To be effective, it is necessary to have programs for developing long-term partnerships among destination stakeholders.

This study has several limitations that provide directions for future studies. First, this study examined its hypothesized research model in one particular destination; therefore, the findings may not be generalizable to other destination settings. Second, the DSR dimensions adapted in this study were based on the extant literature of CSR. In some cases, the theory of CSR may not completely be suitable for a destination. As a newly developed construct, DSR needs to be refined and improved on both the conceptualization and measurement scales. Third, although emotions associated with tourism experience and social responsibility are very diverse, the present study only used three types of emotions-excitement, happiness, and relaxation—to verify the hypotheses. Future research needs to study different types of emotions, such as pleasure, interest, and gratitude, in relation to providing more insights into the effects of DSR.

Author Contributions: Conceptualization, Y.S.H.; formal analysis, H.A.T.T. and C.Y.; investigation, Y.S.H. and S.J.Y.; writing of the original draft, H.A.T.T. and S.J.Y.

Funding: This study received no external funding.

Acknowledgments: This work was supported by the Ministry of Education of the Korea and the National Research Foundation of Korea (NRF-2016S1A5B6925462). This research was also supported by the Sookmyung Women's University Research Grant 1-1603-2021.

Conflicts of Interest: The authors declare no conflicts of interest.

\section{References}

1. Sheldon, P.J.; Park, S.Y. An exploratory study of corporate social responsibility in the US travel industry. J. Travel Res. 2011, 50, 392-407. [CrossRef]

2. Bowen, H.R. Social Responsibility of the Businessman; Harper and Row: New York, NY, USA, 1999.

3. Su, L.; Wang, L.; Law, R.; Chen, X.; Fong, D. Influences of destination social responsibility on the relationship quality with residents and destination economic performance. J. Travel Tour. Mark. 2017, 34, 488-502. [CrossRef]

4. Su, L.; Swanson, S.R. The effect of destination social responsibility on tourist environmentally responsible behaviour: Compared analysis of first-time and repeat tourists. Tour. Manag. 2017, 60, 308-321. [CrossRef]

5. Su, L.; Huang, S.; Huang, J. Effects of Destination Social Responsibility and Tourism Impacts on Residents' Support for Tourism and Perceived Quality of Life. J. Hosp. Tour. Res. 2016, 42, 1039-1057. [CrossRef]

6. Papadimitriou, D.; Kaplanidou, K.; Apostolopoulou, A. Destination image components and word-of-mouth intentions in urban tourism: A multigroup approach. J. Hosp. Tour. Res. 2015, 5, 1-21. [CrossRef]

7. Smith, R.A.; Ong, J.L.T. Corporate social responsibility and the operationalization challenge for global tourism organizations. Asia Pac. J. Tour. Res. 2015, 20, 487-499. [CrossRef] 
8. Baron, R.M.; Kenny, D.A. The moderator-mediator variable distinction in social psychological research: Conceptual, strategic, and statistical considerations. J. Personal. Soc. Psychol. 1986, 51, 1173-1182. [CrossRef]

9. Ladhari, R. The effect of consumption emotions on satisfaction and word-of-mouth communications. Psychol. Mark. 2007, 24, 1085-1108. [CrossRef]

10. Yuksel, A.; Yuksel, F. Shopping risk perceptions: Effects on tourists' emotions, satisfaction and expressed loyalty intentions. Tour. Manag. 2007, 28, 703-713. [CrossRef]

11. Io, M.U. Exploring the impact of hedonic activities on casino-hotel visitors' positive emotions and satisfaction. J. Hosp. Tour. Manag. 2016, 26, 27-35. [CrossRef]

12. Jung, H.S.; Yoon, H.H. The effects of nonverbal communication of employees in the family restaurant upon customers' emotional responses and customer satisfaction. Int. J. Hosp. Manag. 2011, 30, 542-550. [CrossRef]

13. MacKinnon, D.P.; Fairchild, A.J.; Fritz, M.S. Mediation analysis. Annu. Rev. Psychol. 2007, 58, 593-614. [CrossRef] [PubMed]

14. Mehrabian, A.; Russell, J.A. An Approach to Environmental Psychology; The MIT Press: Cambridge, MA, USA, 1974.

15. Robert, D.; John, R. Store atmosphere: An environmental psychology approach. J. Retail. 1982, 58, 34-57.

16. Bagozzi, R.P.; Gopinath, M.; Nyer, P.U. The role of emotions in marketing. J. Acad. Mark. Sci. 1999, 27, 184-206. [CrossRef]

17. Grappi, S.; Montanari, F. The role of social identification and hedonism in affecting tourist re-patronizing behaviours: The case of an Italian festival. Tour. Manag. 2011, 32, 1128-1140. [CrossRef]

18. Yǘksel, A. Tourist shopping habitat: Effects on emotions, shopping value and behaviors. Tour. Manag. 2007, 28, 58-69. [CrossRef]

19. Han, H.; Jeong, C. Multi-dimensions of patrons' emotional experiences in upscale restaurants and their role in loyalty formation: Emotion scale improvement. Int. J. Hosp. Manag. 2013, 32, 59-70. [CrossRef]

20. Del Bosque, I.R.; San Martín, H. Tourist satisfaction a cognitive-affective model. Ann. Tour. Res. 2008, 35, 551-573. [CrossRef]

21. Edwards, D. Corporate social responsibility of large urban museums: The contribution of volunteer programs. Tour. Rev. Int. 2007, 11, 167-174. [CrossRef]

22. Xu, X.L.; Lee, M.J.; Hwang, Y.S. The effect of environment responsibility of eco-tourism on destination image and tourists' loyalty: Focusing on visitors at Mt. Halla in Jeju Island. Int. J. Tour. Manag. Sci. 2016, 31, 1-17.

23. Ma, B.; Su, L.; Ding, Y.; Hu, X. Understanding the Relationships among Destination Social Responsibility, Resident Benefits, Trust and Support for Tourism Development. Inf. Technol. J. 2013, 12, 22-34.

24. Westbrook, R.A.; Oliver, R.L. The dimensionality of consumption emotion patterns and consumer satisfaction. J. Consum. Res. 1991, 18, 84-91. [CrossRef]

25. Hosany, S.; Prayag, G. Patterns of tourists' emotional responses, satisfaction, and intention to recommend. J. Bus. Res. 2013, 66, 730-737. [CrossRef]

26. Watson, D.; Clark, L.A.; Tellegen, A. Development and validation of brief measures of positive and negative affect: The PANAS scales. J. Personal. Soc. Psychol. 1988, 54, 1063. [CrossRef]

27. Izard, C.E. Human Emotions; Plenum: New York, NY, USA, 1977.

28. Richins, M.L. Measuring emotions in the consumption experience. J. Consum. Res. 1997, 24, 127-146. [CrossRef]

29. Hosany, S.; Gilbert, D. Measuring tourists' emotional experiences toward hedonic holiday destinations. J. Travel Res. 2010, 49, 513-526. [CrossRef]

30. Lee, Y.K.; Lee, C.K.; Lee, S.K.; Babin, B.J. Festivalscapes and patrons' emotions, satisfaction, and loyalty. J. Bus. Res. 2008, 61, 56-64. [CrossRef]

31. Hosany, S.; Prayag, G.; Deesilatham, S.; Cauševic, S.; Odeh, K. Measuring tourists' emotional experiences: Further validation of the destination emotion scale. J. Travel Res. 2015, 54, 482-495. [CrossRef]

32. Chen, C.F.; Tsai, D. How destination image and evaluative factors affect behavioural intentions? Tour. Manag. 2007, 28, 1115-1122. [CrossRef]

33. Chon, K.S. Understanding recreational traveler's motivation, attitude and satisfaction. Tour. Rev. 1989, 44, 3-7. [CrossRef]

34. Um, S.; Chon, K.; Ro, Y. Antecedents of revisit intention. Ann. Tour. Res. 2006, 33, 1141-1158. [CrossRef]

35. Kozak, M.; Rimmington, M. Tourist satisfaction with Mallorca, Spain, as an off-season holiday destination. J. Travel Res. 2000, 38, 260-269. [CrossRef] 
36. Kim, J.S.; Song, H.; Lee, C.K.; Lee, J.Y. The impact of four CSR dimensions on a gaming company's image and customers' revisit intentions. Int. J. Hosp. Manag. 2017, 61, 73-81. [CrossRef]

37. Lee, C.K.; Lee, Y.K.; Lee, B. Korea's destination image formed by the 2002 World Cup. Ann. Tour. Res. 2005, 32, 839-858. [CrossRef]

38. Su, L.; Swanson, S.R.; Chen, X. Social responsibility and reputation influences on the intentions of Chinese Huitang Village tourists: Mediating effects of satisfaction with lodging providers. Int. J. Contemp. Hosp. Manag. 2015, 27, 1750-1771. [CrossRef]

39. Bhattacharya, C.B.; Sen, S. Consumer-company identification: A framework for understanding consumers' relationships with companies. J. Mark. 2003, 67, 76-88. [CrossRef]

40. Sen, S.; Bhattacharya, C.B. Does doing good always lead to doing better? Consumer reactions to corporate social responsibility. J. Mark. Res. 2001, 38, 225-243. [CrossRef]

41. Perez, A.; Del Bosque, I.R. An integrative framework to understand how CSR affects customer loyalty through identification, emotions and satisfaction. J. Bus. Ethics 2015, 129, 571-584. [CrossRef]

42. Lichtenstein, D.R.; Drumwright, M.E.; Braig, B.M. The effect of corporate social responsibility on customer donations to corporate-supported nonprofits. J. Mark. 2004, 68, 16-32. [CrossRef]

43. Luo, X.; Bhattacharya, C.B. Corporate social responsibility, customer satisfaction, and market value. J. Mark. 2006, 70, 1-18. [CrossRef]

44. Prayag, G.; Ryan, C. Antecedents of tourists' loyalty to Mauritius: The role and influence of destination image, place attachment, personal involvement, and satisfaction. J. Travel Res. 2012, 51, 342-356. [CrossRef]

45. Chi, C.G.Q.; Qu, H. Examining the structural relationships of destination image, tourist satisfaction and destination loyalty: An integrated approach. Tour. Manag. 2008, 29, 624-636. [CrossRef]

46. Chen, C.F.; Phou, S. A closer look at destination: Image, personality, relationship and loyalty. Tour. Manag. 2013, 36, 269-278. [CrossRef]

47. Prayag, G.; Hosany, S.; Odeh, K. The role of tourists' emotional experiences and satisfaction in understanding behavioural intentions. J. Destin. Mark. Manag. 2013, 2, 118-127.

48. Bigné, J.E.; Andreu, L.; Gnoth, J. The theme park experience: An analysis of pleasure, arousal and satisfaction. Tour. Manag. 2005, 26, 833-844. [CrossRef]

49. Carroll, A.B. A three-dimensional conceptual model of corporate performance. Acad. Manag. Rev. 1979, 4, 497-505. [CrossRef]

50. Carroll, A.B. The pyramid of corporate social responsibility: Toward the moral management of organizational stakeholders. Bus. Horiz. 1991, 34, 39-48. [CrossRef]

51. Dahlsrud, A. How corporate social responsibility is defined: An analysis of 37definitions. Corp. Soc. Resp. Environ. Manag. 2008, 15, 1-13. [CrossRef]

52. Jang, Y.Y. A Study on the Effects of Hotel Businesses' Perceived Corporate Social Responsibility Activities on Their Corporate Image, Customer Satisfaction and Behavioural Intention. Ph.D. Thesis, Kyung Hee University, Seoul, Korea, 2017.

53. Tamajón, L.G.; Font, X. Corporate social responsibility in tourism small and medium enterprises evidence from Europe and Latin America. Tour. Manag. Perspect. 2013, 7, 38-46. [CrossRef]

54. Fatma, M.; Rahman, Z.; Khan, I. Measuring consumer perception of CSR in tourism industry: Scale development and validation. J. Hosp. Tour. Manag. 2016, 27, 39-48. [CrossRef]

55. Martínez, P.; Pérez, A.; Rodríguez del Bosque, I. Measuring corporate social responsibility in tourism: Development and validation of an efficient measurement scale in the hospitality industry. J. Travel Tour. Mark. 2013, 30, 365-385. [CrossRef]

56. Tingchi Liu, M.; Anthony Wong, I.; Shi, G.; Chu, R.L.; Brock, J. The impact of corporate social responsibility (CSR) performance and perceived brand quality on customer-based brand preference. J. Serv. Mark. 2014, 28, 181-194. [CrossRef]

57. Kang, B.J.; Kim, I.S.; Hyun, S.H. The effect of corporate social responsibility on customers' brand identification and customer citizenship behaviour in hotel industry. Int. J. Tour. Manag. Sci. 2016, 31, 191-208.

58. Hultman, M.; Skarmeas, D.; Oghazi, P.; Beheshti, H.M. Achieving tourist loyalty through destination personality, satisfaction, and identification. J. Bus. Res. 2015, 68, 2227-2231. [CrossRef] 
59. Hair, J.F.; Black, W.C.; Babin, B.J. Multivariate Data Analysis: A Global Perspective; Pearson Prentice Hall: Upper Saddle River, NJ, USA, 2010.

60. Lee, J.S.; Son, J.M. The structural Relationship between CSR, trust, customer loyalty, and purchase intention as perceived by customer: Mediating roles of trust. J. Consumpt. Cult. 2015, 18, 67-84. 